\title{
Investigations on the Optical-Electrical-Thermal Characteristics of RGB LEDs
}

\author{
R. Srividya ${ }^{1}$, C.R. Srinivasan ${ }^{2,}$, Winston Netto ${ }^{2}$ \\ ${ }^{1}$ Department of Electrical and Electronics Engineering, Manipal Academy of Higher Education, \\ Manipal Institute of Technology, Manipal, India \\ ${ }^{2}$ Department of Instrumentation and Control Engineering, Manipal Academy of Higher Education, \\ Manipal Institute of Technology, Manipal, India
}

(Received 10 January 2021; revised manuscript received 15 June 2021; published online 25 June 2021)

\begin{abstract}
Heat dissipation is the main problem of concern when working with high power light emitting diodes. If not controlled, the optical and electrical performance of the luminaire can get affected. A higher junction temperature induces variations in forward voltage, luminous lux, correlated color temperature, color point and peak wavelength. LED manufacturers have their operating ranges for junction temperature and driving current. Operating LEDs beyond the operating range of current may initially provide high luminous flux, but junction temperature might increase beyond the range specified, resulting in very fast degradation of luminous flux. Also, elevated junction temperatures can severely affect the lifetime and reliability of LEDs. Hence, measurement and control of junction temperature within the maximum operating range through appropriate thermal design are vital for avoiding performance degradation of the LED luminaire. This paper shows an insight on the experimentations carried out to measure the junction temperature and analyze its effect on the electrical and optical parameters of RGB LEDs within the maximum operating temperature.
\end{abstract}

Keywords: LED, Junction temperature, Heat dissipation, Forward voltage, Luminous flux.

DOI: 10.21272/jnep.13(3).03013

PACS number: 07.07.Hj

\section{INTRODUCTION}

Variations in the optical and electrical parameters of LEDs mainly occur because of junction temperature, ambient temperature and device ageing. Junction temperature $T_{j}$ strongly depends on the drive current and the ambient temperature in which the LED is operated which can be defined as in equation (1):

$$
T_{j}=T_{a}+R_{t h} P_{d}
$$

where $T_{a}$ is the ambient temperature in ${ }^{\circ} \mathrm{C}, R_{t h}$ is the equivalent thermal resistance from junction to ambient in ${ }^{\circ} \mathrm{C} / \mathrm{W}$ and $P_{d}$ is the dissipated power which is the product of forward voltage $\left(V_{f}\right)$ and forward current $\left(I_{f}\right)$ [1]. When there is no self-heating in LEDs $T_{j}=T_{j}=25^{\circ} \mathrm{C}$. As the temperature across the $p$ - $n$ junction raises there will be a decrease in the forward current as well as forward voltage which can be given by equation (2):

$$
I=I_{s} e^{\frac{q V_{f}}{n k T_{j}}},
$$

where $I_{s}$ is the reverse saturation current, $k$ is the Boltzmann constant, $V_{f}$ is the forward voltage, $T_{j}$ is the junction temperature, $I$ is the forward current, $q$ is the electron charge and $n$ is the ideality factor (a constant which has a value from 1 to 2) [2]. Bandgap of the semiconductor material determines the amount of forward voltage that needs to be applied for radiative recombination. Since the color of LEDs depends on the semiconductor material used, when there is a depreciation in the forward voltage, the $p$ - $n$-junction band gap reduces due to which LED color changes. This change is represented as a shift in the $(u v)$ as per CIE 1960 or $\left(u^{\prime} v^{\prime}\right)$ as per CIE 1976 chromaticity diagram. The change in chromaticity coordinates of individual LED causes variations in CCT, peak wavelength and spectral power distribution of the light source. The luminous flux of an LED is directly proportional to the amount of current applied to the LED. With an increase in dissipated power, the amount of optical power given out as useful light decreases, thereby decreasing luminous flux [3]. Hence, measurement and control of junction temperature is of great importance to maintain stability in the performance of a luminaire. Junction temperature cannot be directly measured [4]. In literature, numerous experimental analysis has been carried out in terms of temperature-sensitive parameters (TSP) in three categories namely electrical methods, optical methods, and physical contact methods to accurately estimate junction temperature and study the dependency of junction temperature on the optical and electrical properties of the LEDs [5]. The most often used primary physical contact method is thermocouple but unfortunately, its use is limited due to the small size of the LED chip [6]. The optical methods include peak wavelength shift method, energy slope methods [7], nematic liquid crystal method, radiation energy method [8], electro-luminescence shift method etc. The electrical methods include forward voltage method [9], thermal resistance measurement method etc. Some researchers have also used thermal infra-red imager [10] to estimate the junction temperature from the surface temperature. Among all the above methods, there are tremendous explorations on forward voltage method as it is a less complex mathematical approach, involves simple experimental procedures, does not require the calculation of thermal resistance and much more applicable when combining with the

*cr.srinivasan@manipal.edu

The results were presented at the International Conference on Innovative Research in Renewable Energy Technologies (IRRET-2021) 
control of input drive current. Also, the accuracy of forward voltage method was estimated to be $\pm 3^{\circ} \mathrm{C}$ compared to peak wavelength shift as well as energy slope methods [7]. Using the forward voltage method, an empirical model to relate the dependence of emission spectra of polychromatic LEDs on junction temperature and driving current was proposed in [11]. [12] and [13] have proposed a generalized experimental procedure and a simplified model for luminaire designers to verify thermal management system. According to the recommendations of LED manufacturers if the LEDs are operated within the maximum operating temperature the variations in optical as well as electrical parameters will be within tolerance and will not affect the performance of the luminaire [12]. Hence, this paper outlines the various experimental investigations carried out to analyze the operating temperature of high-power multichip RGB LEDs using forward voltage method and to study as well as practically verify whether the optical and electrical variations within these operating temperatures are in the tolerance range.

\section{RESEARCH METHOD}

\subsection{Junction Temperature Estimation of RGB LEDs}

The forward voltage method is based on the fact that at constant current, the temperature and voltage are linearly related to each other with a negative slope as shown in equation (3). In equation (3), under constant diode current $I, V_{f 1}$ and $V_{f 2}\left(V_{f 1}>V_{f 2}\right)$ are the forward voltages measured at two different junction temperatures $T_{j 1}$ and $T_{j 2}\left(T_{j 1}>T_{j 2}\right), n$ is an ideality factor, $k$ is the Boltzmann constant and $q$ is the electron charge, $K_{i}$ is the constant correlation factor given by $\left(T_{j 2}-T_{j 1}\right) /\left(V_{f 1}-V_{f 2}\right)$ expressed in ${ }^{\circ} \mathrm{C} / \mathrm{mV}$ [12].

$$
\frac{V_{f 1}}{T_{j 1}}-\frac{V_{f 2}}{T_{j 2}}=K_{i} \frac{n k}{q}\left(T_{j 2}-T_{j 1}\right) .
$$

The forward voltage technique was performed in two measurement steps: Calibration and actual measurement. In the calibration step, three Edixeon multichip RGB LEDs were connected in series and placed inside a temperature-controlled oven. The temperature of the oven $\left(T_{0}\right)$ was initialized to $20^{\circ} \mathrm{C}$. Around $30 \mathrm{~min}$ was given for the LEDs to attain thermal equilibrium. Once the oven temperature was established, a single pulse drive current of $I_{\min }=50 \mathrm{~mA}$ was applied to the LEDs for a duration of $0.3 \mathrm{~s}$ and the forward voltage drop was measured. With this short current pulse, the heat dissipated from LED can be ignored, so the junction temperature can be assumed to be the same as the oven temperature. The process was continued as a loop for different increments of temperature and current until the final experimental temperature and current was reached. Enough time was given between successive readings for the LEDs to attain thermal equilibrium under the new oven temperatures. The linear relation between oven temperature $\left(T_{0}\right)$ and forward voltage $\left(V_{f}\right)$ can be expressed as shown in equation (4) where $V_{f 0}$ is the line intercept and $(\Delta V / \Delta T)$ is the slope [12].

$$
V_{f}=\frac{\Delta V}{\Delta T} T_{0}+V_{f 0} .
$$

During actual measurement, the LEDs were placed outside the temperature-controlled oven in the normal operating conditions and were continuously supplied with $350 \mathrm{~mA}$ of maximum drive current. Forward voltage was measured from the start (A) until it attained the saturation level (B) as shown in Fig. 5b, Fig. 6b and Fig. $7 \mathrm{~b}$. Also, the operating temperature at the initial start $\left(T_{\text {initial }}\right)$ was noted. It took almost an hour for the temperature and forward voltage to reach the saturation level. Thus, using the forward voltage values at (A) and (B) as well as the initial start temperature, junction temperature at (B) was estimated using equation (6) obtained by simplifying equation (5) [12]:

$$
\begin{gathered}
\frac{V_{f 1}-V_{f 2}}{T_{j 1}-T_{j 2}}=\frac{\Delta V_{f}}{\Delta T_{j}}=\mathrm{K}, \\
T_{j 2}=T_{j 1}-\frac{V_{f 1}-V_{f 2}}{\Delta V_{f}} \Delta T_{j} .
\end{gathered}
$$

In equation (6), $V_{f 1}$ is the forward voltage at the initial start temperature $T_{j 1}$ at (A) and $V_{f 2}$ is the forward voltage at the steady state (B).

\subsection{Analysis of the Junction Temperature Effect on the Optical Performance of LEDs}

The experimental setup is shown in Fig. 1. Three multichip RGB LEDs placed on separate MCPCBs were mounted on the thermal pad inside the integrating sphere of $0.5 \mathrm{~m}$ diameter attached with spectrophotometer of Labsphere SMS500. The power supply for thermal pad was given using Keysight DC power meter and for LEDs was given through Keithley 2400 series source meter. One after the other, each color in the series combination was supplied continuously with a maximum rated current of $350 \mathrm{~mA}$. The thermal pad temperature was raised in steps from $25^{\circ} \mathrm{C}$ until the forward voltage drop attained saturation. At saturation, the junction temperature was estimated and was found to be the same as obtained in forward voltage method. The thermal pad temperature at which forward voltage and junction temperature attained saturation was $40^{\circ} \mathrm{C}$ for red, $55^{\circ} \mathrm{C}$ for green, and $50{ }^{\circ} \mathrm{C}$ for blue. Considering the thermal pad temperature as an approximation of junction temperature of LEDs at every step rise of thermal pad temperature, chromaticity coordinates, luminous flux and peak wavelength were measured.

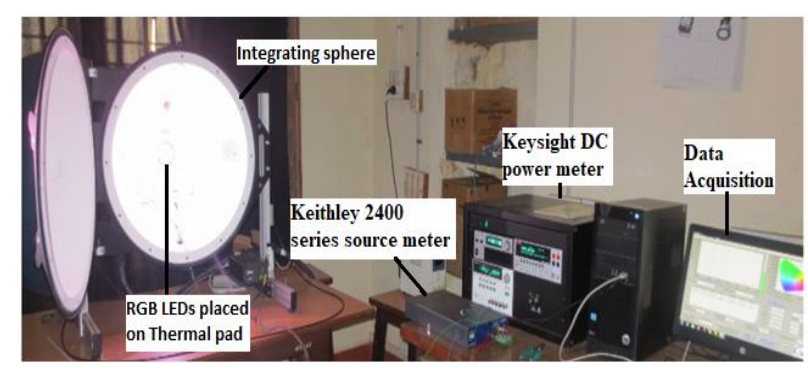

Fig. 1 - Experimental test setup 


\section{RESULTS}

\subsection{Junction Temperature Estimation}

The experimental results of calibration and actual measurement for red LED is shown in Fig. 2. Similar plots were made for green and blue also. From Fig. 2a, it was observed that, the slope $\Delta V / \Delta T$ became steeper as the current was varied from $50 \mathrm{~mA}$ to $350 \mathrm{~mA}$. Red decayed at a faster rate compared to green and blue which was seen by comparing their slopes. From Fig. $2 \mathrm{~b}$, it was observed that, with the maximum drive current of $350 \mathrm{~mA}$ red LED attained saturation at a junction temperature of $49^{\circ} \mathrm{C}$. Similarly, green at $65^{\circ} \mathrm{C}$ and blue at $57^{\circ} \mathrm{C}$. Also, it was seen that the LEDs operated within the maximum junction temperature of $120^{\circ} \mathrm{C}$ recommended by Edixeon.
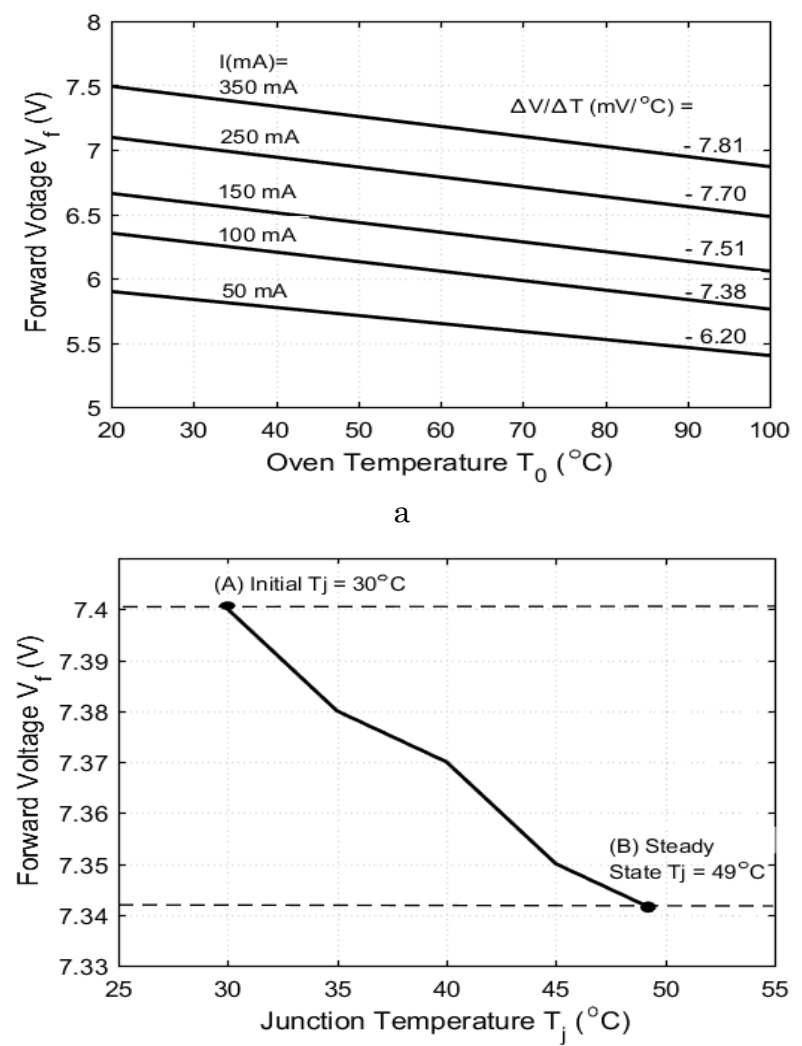

$\mathrm{b}$

Fig. 2 - Red LED: (a) calibration, (b) actual measurement

\subsection{Effect of Junction Temperature on the Optical Performance of LEDs}

The variations produced in the color point in the form of the CIE $1976\left(\boldsymbol{u}^{\prime}, \boldsymbol{v}^{\prime}\right)$ coordinates were observed to be 0.0013 for red, 0.0013 for green and 0.003 for blue. By comparing the luminous flux variation in all three colors red showed the largest decrease of $5.64 \%$ compared to the green of $4.76 \%$ and blue of $1.02 \%$. The peak wavelength shift of $2 \mathrm{~nm}$ was observed in red compared to $1 \mathrm{~nm}$ shift in other two colors. Fig. 3, Fig. 4 and Fig. 5 show the graphical plots of obtained results for red LED. Similar graphs were plotted for other two colors.

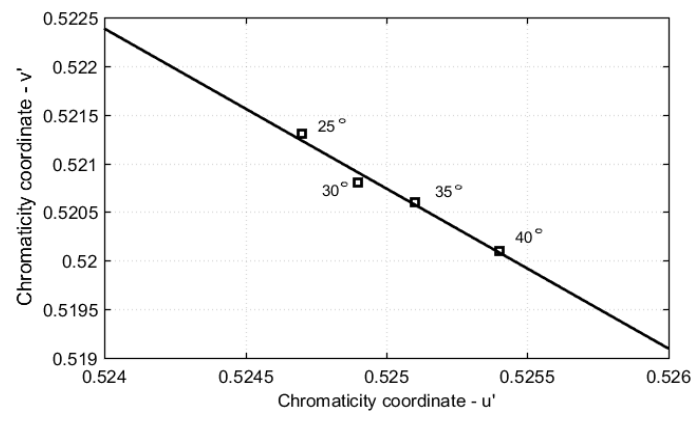

Fig. 3 - Variation of color point in red LED at different thermal pad temperatures

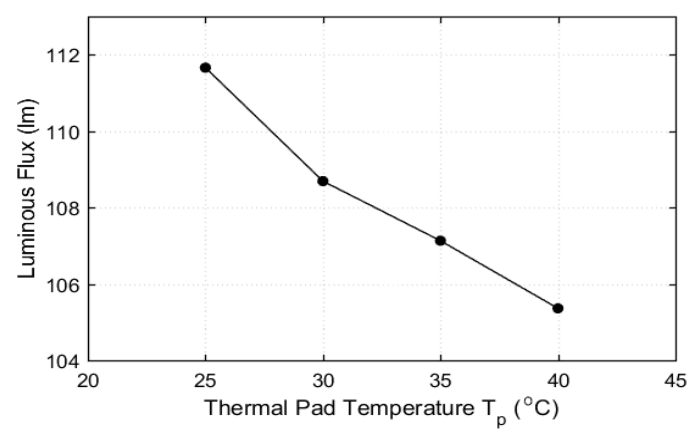

Fig. 4 - Variation of luminous flux with rise of junction temperature at $350 \mathrm{~mA}$ for red LED

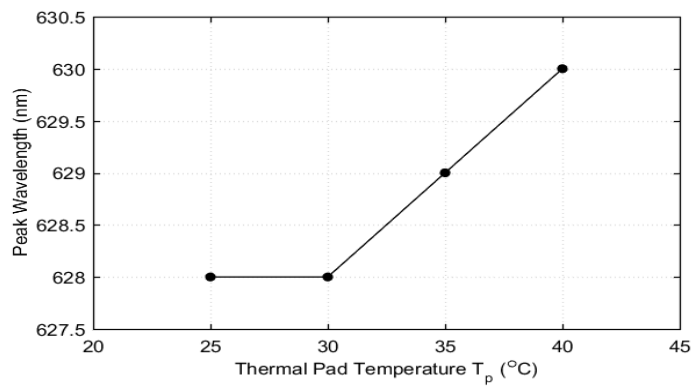

Fig. 5 - Variation in peak wavelength with rise of junction temperature at $350 \mathrm{~mA}$ for red LED

After analyzing individual colors, the required currents for red, green and blue LEDs for producing the CCTs of $6500 \mathrm{~K}, 5000 \mathrm{~K}$ and $7500 \mathrm{~K}$ were applied and the variation in $\mathrm{CCT}$ with junction temperature rise was observed. As the red LED was very much sensitive to temperature it had a large drop in luminous flux compared to other colors. Hence CCT shifted towards the blue and green region. Table 1 shows a comparison of the tolerance limits for variation in color point, luminous flux, peak wavelength as per LED datasheet and obtained values through experimentation. The mentioned tolerance limits for individual colors are for the thermal pad temperature range of $25-40{ }^{\circ} \mathrm{C}$ for red, 25 $55{ }^{\circ} \mathrm{C}$ for green, $25-50{ }^{\circ} \mathrm{C}$ for blue. The tolerance limits for the RGB combination are taken for the thermal pad temperature range of $25^{\circ} \mathrm{C}-60^{\circ} \mathrm{C}$ considering the maximum thermal pad temperature at which green attains saturation. It was observed that the variations in the obtained values were within acceptable limits [14]. 
Table 1 -Tolerance limits for shifts in optical parameters as per Edixeon Datasheet

\begin{tabular}{|c|c|c|c|c|c|c|c|c|c|c|}
\hline \multirow{3}{*}{ Parameters } & \multicolumn{4}{|c|}{ Tolerance Limits } & \multicolumn{6}{|c|}{ Obtained values } \\
\hline & \multicolumn{3}{|c|}{ Individual } & \multirow{2}{*}{\begin{tabular}{|c} 
Combined \\
RGB
\end{tabular}} & \multicolumn{3}{|c|}{ Individual } & \multicolumn{3}{|c|}{ Combined (RGB) } \\
\hline & Red & Green & Blue & & Red & Green & Blue & 5001 & 6503 & 7505 \\
\hline Shift in $\Delta u^{\prime} v^{\prime}$ & & $<0.006$ & & $<0.006$ & 0.0013 & 0.0013 & 0.003 & 0.004 & 0.004 & 0.005 \\
\hline Drop in luminous flux (\%) & $\leq 21 \%$ & $\leq 6 \%$ & $\leq 6 \%$ & $\leq 70 \%$ & $5.64 \%$ & $4.76 \%$ & $1.02 \%$ & $13.5 \%$ & $13.5 \%$ & $12.7 \%$ \\
\hline Shift in peak wavelength (nm) & $\leq 3 \mathrm{~nm}$ & $\leq 1 \mathrm{~nm}$ & $\leq 2 \mathrm{~nm}$ & $\leq 6 \mathrm{~nm}$ & $2 \mathrm{~nm}$ & $1 \mathrm{~nm}$ & $1 \mathrm{~nm}$ & $5 \mathrm{~nm}$ & $4 \mathrm{~nm}$ & $5 \mathrm{~nm}$ \\
\hline $\operatorname{CCT}(\mathrm{K})$ & - & - & - & $\pm 350 \mathrm{~K}$ & - & - & - & $165 \mathrm{~K}$ & $227 \mathrm{~K}$ & $187 \mathrm{~K}$ \\
\hline
\end{tabular}

\section{CONCLUSIONS}

The pilot studies performed on RGB LEDs to investigate their operating temperature showed a rise of $49{ }^{\circ} \mathrm{C}$ for red, $65{ }^{\circ} \mathrm{C}$ for green and $57^{\circ} \mathrm{C}$ for blue for a maximum drive current of $350 \mathrm{~mA}$. Also, the variations in LED parameters within these temperatures were found to be within the manufacturer limits. Hence, it can be inferred that with low drive current the rise of junction temperature can be controlled within limits and luminaire performance will not be affected. The outcome of the preliminary experiments in this paper will encourage the luminaire designers to design luminaries with low drive current and maintain the overall junction temperature within the recommended limits with appropriate thermal management system for safe operation of the luminaire.

\title{
REFERENCES
}

1. T. Tetzlaff, U. Witkowski, IEEE Eur. Modelling Symp., 223 (2016)

2. F.D.R. Abbing, M.A. Pertijs, 2011 IEEE Sensors, 861 (2011).

3. Subramanian Muthu, F.J.P. Schuurmans, M.D. Pashley, IEEE J. Select. Topics Quant. Electron. 8 No 2, 333 (2002).

4. R. Srividya, Ciji Pearl Kurian, Int. Conf. Adv. Energy Conversion Technol. (ICAECT-2014), 203 (2014).

5. C.Y. Ho, S.F. Wan, B.C. Chen, L.G. Li, S.Li Fan, C.W. Xiong, Opt. Quant. Electron. 50 No 1, 395 (2018).

6. Y. Xiao, Ting-Zhu Wu, Si-Jia Dang, Yu-Lin Gao, Yue Lin, Li-Hong Zhu, IEEE Trans. Electron Dev. 64 No 5, 2257 (2017).

7. S. Chhajed, Yangang Xi, Th Gessmann, Jing-Qun Xi, Light-Emitting Diodes: Research, Manufacturing, and Applications IX 5739, 16 (2005).

8. Yimin Gu, Nadarajah Narendran, Third Int. Conf. Solid State Light. 5187, 107 (2004).

9. Y. Xi, E.F. Schubert, Appl. Phys Lett. 85 No 12, 2163 (2004).

10. X. Long, R. Liao, J. Zhou, Z. Zeng, Electron. Lett. 47 No 20, 1142 (2011).

11. H.Y. Chou, T.H. Yang, J. Light Visual Env. 32 No 2, 183 (2008).

12. K.R. Shailesh, C.P. Kurian, S.G. Kini, Light. Res. Technol. 47 No 5, 620 (2015).

13. A.N. Padmasali, S.G. Kini, Light. Res. Technol. (2019).

14. Subramanian Muthu, James Gaines et al., 38th IAS Annual Meeting on Conference Record of the Industry Applications Conference, 515 (2003).

\section{Дослідження оптико-електричних та теплових характеристик світлодіодів RGB}

\author{
R. Srividya1, C.R. Srinivasan ${ }^{2}$, Winston Netto ${ }^{2}$ \\ ${ }^{1}$ Department of Electrical and Electronics Engineering, Manipal Academy of Higher Education, \\ Manipal Institute of Technology, Manipal, India \\ ${ }^{2}$ Department of Instrumentation and Control Engineering, Manipal Academy of Higher Education, \\ Manipal Institute of Technology, Manipal, India
}

\begin{abstract}
Відведення тепла є основною проблемою, яка викликає занепокоєння при роботі зі світлодіодами великої потужності. Якщо не контролювати, оптичні та електричні характеристики освітлювального приладу можуть постраждати. Більш висока температура переходу спричиняе коливання прямої напруги, світлових потоків, корельованої колірної температури, колірної точки та пікової довжини хвилі. Виробники світлодіодів мають свої робочі діапазони для температури переходу і струму збудження. Світлодіоди, які працюють за рамками робочого діапазону струму, спочатку можуть забезпечувати високий світловий потік, але температура переходу може збільшуватися поза вказаним діапазоном, що призводить до дуже швидкого погіршення світлового потоку. Крім того, підвищені температури переходів можуть серйозно вплинути на термін служби та надійність світлодіодів. Отже, вимірювання та контроль температури переходу в максимальному робочому діапазоні через відповідну теплову конструкцію е життево важливими для уникнення погіршення продуктивності освітлювального приладу. У статті представлені результати експериментів, проведених для вимірювання температури переходу та аналізу їі впливу на електричні та оптичні параметри світлодіодів RGB в межах максимальної робочої температури.
\end{abstract}

Ключові слова: Світлодіод, Температура переходу, Відведення тепла, Пряма напруга, Світловий потік. 